curred with three eclipta plants per pot, indicating the competitive nature of eclipta (Table 3). Although not compared statistically, eclipta dry weights were higher in large than in small containers, indicating that the size of the 3.8-liter containers may have limited eclipta growth. Consistent weed weights at the three, six, and nine density levels in year 1 support this observation.

Maximum prostrate spurge shoot dry weights occurred with six or nine weeds per pot. Only with 'Crimson Pigmy' in 15.2-liter containers did three spurge per pot result in maximum weed weights. These data suggest that prostrate spurge is not as competitive as eclipta, where maximum weed weights occurred with three weeds per pot.

Maximum wood sorrel shoot dry weights generally occurred with nine weeds per pot (Table 3). These data, coupled with limited suppression of ornamental growth, demonstrate that wood sorrel is relatively non-competitive. Previous research had also shown bittercress (Cardamine) to have limited effects on woody plant growth (Wilbourn and Rauch, 1972).

Weeds and ornamental plants vary in their competitiveness. The results of this study indicate that competition from some weeds, but not all, significantly reduces plant growth of woody plants during container production. With two of the problem weed species in the southeastern United States container nurseries, one weed per container limits woody plant growth.

\section{Literature Cited}

Buchanan, G. A., J.E. Street, and R.H. Crowley. 1980. Influence of time of planting and distance from the cotton row of pitted morningglory, prickly sida, and redroot pigweed on competitiveness with cotton. Weed Sci. 28:568-572

Dawson, J.G. 1965. Competition between irrigated sugar beets and annual weeds. Weeds 13:245-249.

Fretz, T.A. 1972. Weed competition in container grown Japanese holly. HortScicnce 7:485-486.

Hill, L.V. and P.W. Santlemann. 1969. Competitive effects of annual weeds in Spanish peanuts. Weed Sci. 17:1-2.

Lawson, H.M. 1974. The effects of weeds on fruit and ornamental crops. Scottish Hort. Res. Inst., Invergowrie, Dundee U.K. p. 1159-1169.

Walker, K.L. and David J. Williams. 1989. Annual grass interference in container-grown bush cinquefoil (Potentilla fruiticosa). Weed Sci. 37:73-75.

Wilbourn, T.A. and F.D. Rauch. 1972. Weed competition in container grown nursery stock. HortScience 7:341. (Abstr.)

\title{
Growth Regulators Combined with Grafting Increase Flower Number and Seed Production in Sweet Potato
}

\author{
Ricard D. Lardizabal and Paul G. Thompson \\ Department of Horticulture, P. O. Drawer T, Mississippi State, \\ MS 39762
}

\author{
Additional index words. Ipomoea batatas, Ipomoea camea spp. fistulosa, BA, 2,4-D, \\ ethephon, $\mathrm{GA}_{3}$
}

\begin{abstract}
Four sweet potato [Ipomoea batatas (L.) Lam.] cultivars responded differently to growth regulator application for number of flowers produced, percentage capsule set, and number of seeds produced. Gibberellic acid, 2,4-D, and BA application resulted in the highest number of flowers by 'Jewel', 'Shore Gold', and 'Vardaman' plants, respectively. Application of $\mathrm{GA}_{3}$ to 'Jewel', 2,4-D or ethephon to 'Shore Gold', and BA to 'Vardaman' produced the highest number of seeds. Grafting to rootstock of Z. carnea Jacq. spp. fistulosa (Mart. ex Choisy) D. Austin increased flower numbers, percentage capsule set, and number of seeds in all cultivars. The effects of growth regulators and grafting were additive for flower numbers, percentage capsule set, and number of seeds. Chemical names used: N-(phenylmethyl)-1H-purin-6-amine (BA), (2,4 -dichlorophenoxy) acetic acid (2,4-D), (2-chloroethyl) phosphoric acid (ethephon), and $(1 \alpha, 2 \beta, 4 a \alpha, 4 b \beta, 10)-2,4 a, 7-t r i h y d r o x y-1-m e t h y 1-8-m e t h y l e n e g i b b-3-e n e-1,10-$ dicarboxylic acid 1,4a-Iactone (gibberellic acid; $\mathbf{G A}_{3}$ ).
\end{abstract}

Some sweet potato cultivars with desirable characteristics produce few flowers and fruit set is low. 'Jewel' and 'Shore Gold' are two high-performing cultivars that flower sparsely or not at all when grown at Starkville, Miss., but should be valuable parents if hybridizations were possible.

Application of the growth regulators 2,4$\mathrm{D}$ and $\mathrm{GA}_{3}$ to sweet potato plants has been

\footnotetext{
Received for publication 20 Sept. 1988. Mississippi Agricultural and Forestry Experiment Station Article no. J-7018. The cost of publishing this paper was defrayed in part by the payment of page charges. Under postal regulations, this paper therefore must be hereby marked advertisement solely to indicate this fact.
}

reported to increase flower numbers (Howell and Wittwer, 1954, 1955; Suge, 1977). In a preliminary glasshouse study, which included the application of four growth regulators to two cultivars, $\mathrm{GA}_{3}$ application resulted in the highest flower production by 'Shore Gold' plants (Lardizabal and Thompson, 1988). Flower numbers following ethephon application were lower than with $\mathrm{GA}_{3}$, but higher than for the control.

Little is known regarding the effect of growth regulators on capsule set in sweet potato. Set was improved in a West Indian breeding line by applying 2,4-D in lanolin to flower pedicels following self-incompatible and cross-incompatible pollinations (Charles et al., 1974); that result indicates the possibility of increasing capsule set by growth regulator applications.

Flower numbers were also increased by grafting sweet potato to rootstock of different Ipomoea spp. (Dukes and Jones, 1981; Folquer, 1961; Folquer and Roncedo, 1974; Kehr et al., 1955; Lam and Cordner, 1955; Lam et al., 1959; Lardizabal and Thompson, 1988; Zobel and Hanna, 1953). I. carnea rootstock was considered optimal for flower induction in sweet potato scions because of increased flower numbers, vigor, ease of handling, and disease tolerance (Dukes and Jones, 1981; Folquer, 1961; Folquer and Roncedo, 1974; Kehr et al., 1955). To the best of our knowledge, the effect of grafting on capsule set has not been reported.

We have grafted to $I$. carnea and obtained limited flowering in the low-flowering cultivars Jewel and Shore Gold. However, because of few flowers and low capsule set, few crosses have been possible. This study was the final part of a two-stage experiment to determine methods of increasing flower numbers, capsule set, and seed production. Preliminary glasshouse trials were conducted during the spring season (March-June). Among factors investigated, $\mathrm{GA}_{3}$ and ethephon in one experiment and grafting to $\mathrm{I}$. carnea in a separate experiment increased the number of flowers produced by 'Shore Gold' (Lardizabal and Thompson, 1988). The final part of the study, reported here, was conducted "to compare flowering response to growth regulator application and grafting among seasons and additional cultivars. The specific objectives of the study were to: a) evaluate further the effectiveness of four growth regulators in combination with grafting for increasing flower production, percentage capsule set, and number of seeds produced during the summer; and b) determine if the effects of growth regulator application and grafting to I. carnea on flower number, capsule set, and seed production were additive.

Plants were transplanted to field plots at 
Table 1. Number of flowers produced on four sweet potato cultivars in response to grafting to I. carnea rootstock and growth regulator application.

\begin{tabular}{|c|c|c|c|c|c|c|c|}
\hline \multirow[b]{3}{*}{ Cultivar } & \multirow[b]{3}{*}{ Grafted } & \multicolumn{6}{|c|}{ No. flowers/plant ${ }^{2}$} \\
\hline & & \multicolumn{6}{|c|}{ Growth regulator } \\
\hline & & $\mathrm{BA}$ & Ethephon & $\mathrm{GA}_{3}$ & 2,4-D & Control & Mean \\
\hline Jewel & $\begin{array}{l}\text { Yes } \\
\text { No } \\
\text { Mean }\end{array}$ & $\begin{array}{c}27 \\
5 \\
16 \mathrm{~b}\end{array}$ & $\begin{array}{c}36 \\
3 \\
20 \mathrm{~b}\end{array}$ & $\begin{array}{r}81 \\
7 \\
44 a\end{array}$ & $\begin{array}{l}12 \\
3 \\
8 b\end{array}$ & $\begin{array}{l}4 \\
1 \\
3 \mathrm{~b}\end{array}$ & $\begin{array}{r}32 \mathrm{a} \\
4 \mathrm{~b} \\
\cdots\end{array}$ \\
\hline Shore Gold & $\begin{array}{c}\text { Yes } \\
\text { No } \\
\text { Mean }\end{array}$ & $\begin{array}{l}0 \\
0 \\
0 \mathrm{~b}\end{array}$ & $\begin{array}{l}12 \\
0 \\
6 \mathrm{ab}\end{array}$ & $\begin{array}{l}26 \\
4 \\
5 \mathrm{ab}\end{array}$ & $\begin{array}{c}38 \\
0 \\
19 \mathrm{a}\end{array}$ & $\begin{array}{l}1 \\
0 \\
0 \mathrm{~b}\end{array}$ & $\begin{array}{r}18 \mathrm{a} \\
1 \mathrm{~b} \\
\cdots\end{array}$ \\
\hline Southern Delite & $\begin{array}{c}\text { Yes } \\
\text { No } \\
\text { Mean }\end{array}$ & $\begin{array}{l}2869 \\
1796 \\
2333 \text { a }\end{array}$ & $\begin{array}{c}1876 \\
694 \\
1285 \mathrm{~b}\end{array}$ & $\begin{array}{l}2562 \\
1539 \\
2051 \text { a }\end{array}$ & $\begin{array}{l}1133 \\
506 \\
820 b\end{array}$ & $\begin{array}{l}2317 \\
1576 \\
1947 \text { a }\end{array}$ & $\begin{array}{c}2151 \mathrm{a} \\
1222 \mathrm{~b} \\
\ldots-.\end{array}$ \\
\hline $\begin{array}{l}\text { Vardaman } \\
\qquad\end{array}$ & $\begin{array}{c}\text { Yes } \\
\text { No } \\
\text { Mean }\end{array}$ & $\begin{array}{r}1158 \\
8 \\
583 \text { a }\end{array}$ & $\begin{array}{c}658 \\
3 \\
331 b\end{array}$ & $\begin{array}{c}736 \\
4 \\
370 \mathrm{~b}\end{array}$ & $\begin{array}{r}214 \\
5 \\
110 \mathrm{c}\end{array}$ & $\begin{array}{c}594 \\
2 \\
298 \mathrm{~b}\end{array}$ & $\begin{array}{r}672 \mathrm{a} \\
4 \mathrm{~b} \\
\ldots\end{array}$ \\
\hline
\end{tabular}

${ }^{2}$ Mean separation among growth regulators within cultivars, and graft treatments within cultivars, by Duncan's multiple range test, $P=0.05$, using square-root-transformed data. Back-transfomed means are presented.

Table2. Percentage capsule set of four sweet potato cultivars in response to grafting to I. carnea rootstocks and growth regulator application.

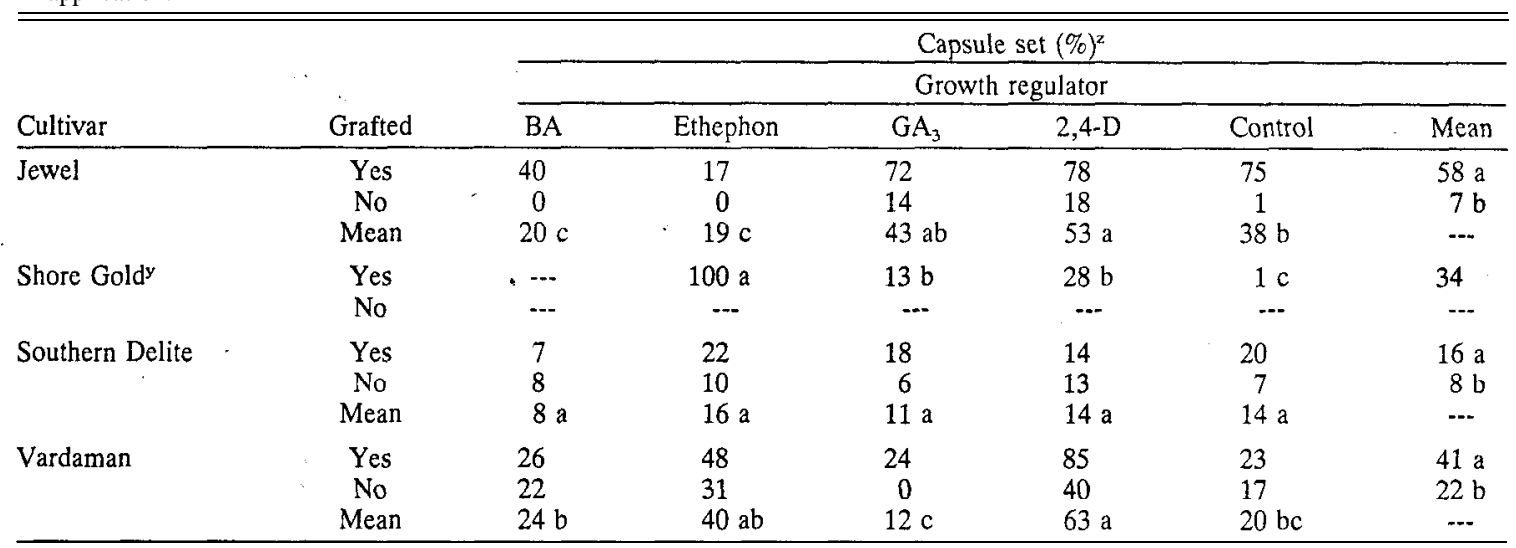

${ }^{2}$ Mean separation among growth regulators within cultivars, and graft treatments within cultivars, by Duncan's multiple range test, $P=0.05$, using arcsin-transformed data. Back-transformed means are presented.

${ }^{y}$ No flowers were produced on nongraf ted or BA-treated 'Shore Gold' plants. Mean separations among growth regulators were based on an analysis of variance, excluding nongrafted and BA-treated plants.

Starkville, Miss. (lat. $\left.33.5^{\circ} \mathrm{N}\right)$, on 19 June 1986 to begin a $2 \times 4 \times 5$ factorial experiment in randomized complete blocks with four replications of one plant per treatment. The treatments were: a) grafted to I. carnea and nongrafted; b) four cultivars, in increasing order of flower numbers normally produced, 'Shore Gold', 'Jewel', 'Vardaman', and 'Southern Delite'; and c) (all in mg.liter $\left.{ }^{-1}\right) 200 \mathrm{BA}, 200$ ethephon, $300 \mathrm{GA}_{3}$, 15 2,4-D, and a water control.

Terminal vine cuttings $0.10 \mathrm{~m}$ long were grafted to $0.15-\mathrm{m}$-long rooted $I$. carnea stock plants using a cleft graft. Nongrafted plants were 0.25 - $\mathrm{m}$ terminal vine cuttings that were rooted before transplanting to field plots. Plants were spaced $2.4 \mathrm{~m}$ apart in rows 2.9 $m$ wide. Row direction was north-south (direction of prevailing wind) and treatments were applied to alternate plants so that treated plants were bordered by guard plants on both sides within the row. Plants were trellised on wires supported by metal posts $1.6 \mathrm{~m}$ high.

Growth regulators were applied to runoff on 8 Aug. as aqueous foliar sprays with $0.1 \%$ Tween 20 as a surfactant.
The number of flowers was counted daily until 30 Sept. Capsules were harvested at maturity and seeds were removed by hand to determine percentage capsule set and number of seeds produced.

The number of flowers and of seeds was transformed to square roots before analyses were performed. Arcsin transformation was used for percentage capsule set. Analyses of variance and mean separations were performed to determine treatment effects on measured variables.

Flower number was analyzed by week, month, and total flowers. Results were similar for all time periods; therefore, only totals are reported.

Gibberellic acid application significantly increased the number of flowers in 'Jewel' (Table 1). In 'Shore Gold', 2,4-D significantly increased flower numbers; however, they were low among all treatments. Growth regulators did not increase flower numbers in 'Southern Delite', which flowered profusely without treatment; however, ethephon and 2,4-D application reduced flower production below the control. The application of 2,4-D to 'Vardaman' also reduced flower production below the control treatment, and BA application resulted in the highest number of flowers on plants of that cultivar.

These results agree with those of an earlier trial conducted during Spring 1987 showing that $\mathrm{GA}_{3}$ or ethephon increased flower numbers over the control in 'Shore Gold' $(2,4$ D was not included) (Lardizabal and Thompson, 1988). Total flower numbers and differences in flower numbers among growth regulator treatments were higher in the spring study, indicating a possible season $\mathbf{x}$ growth regulator interaction.

Also noteworthy was that BA-treated 'Vardaman' plants produced significantly more flowers than control plants. In a previous study, BA did not increase flower production in 'Shore Gold' or 'Southern Delite' (Lardizabal and Thompson, 1988).

Grafting to I. carnea had a profound positive effect on number of flowers produced by all cultivars (Table 1), confirming previous results (Dukes and Jones, 1981; Folquer, 1961; Folquer and Roncedo, 1974; Kehr et al., 1955; Lardizabal and Thomp- 
Table 3. Number of seeds produced by four sweet potato cultivars in response to grafting to I. carnea rootstock and growth regulator application.

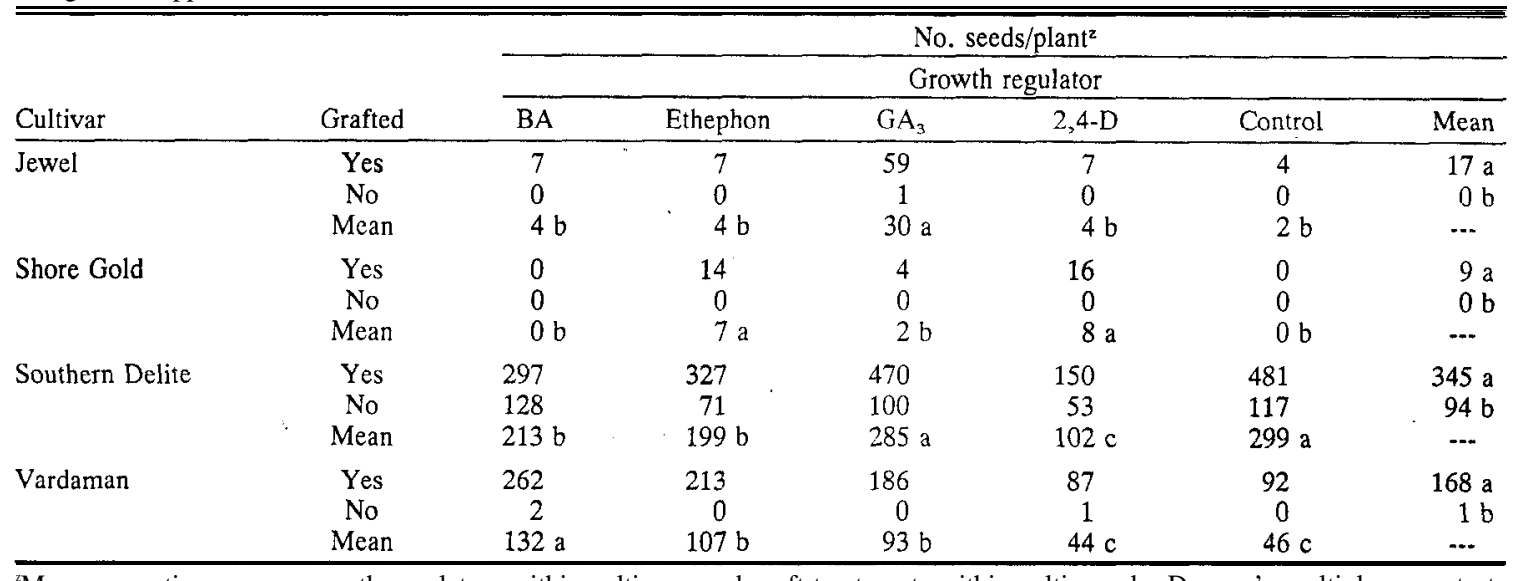

${ }^{ }$Mean separation among growth regulators within cultivars, and graft treatments within cultivars, by Duncan's multiple range test, $P=0.05$, using square-root-transformed data. Back-transformed means are presented.

son, 1988). The lack of interaction for flower number between grafting and growth regulators suggests similar flowering responses to growth regulator application among grafted and nongrafted plants.

There was interaction between growth regulators and cultivars for percentage capsule set (Table 2). 'Jewel' and 'Vardaman' plants had the highest percentage set with 2,4-D. Ethephon application resulted in the highest percentage set in 'Shore Gold'. Grafting onto I. carnea increased percentage capsule set for all cultivars that could be measured, with the largest increase occurring in 'Jewel', which produced the fewest flowers (Table 2).

Growth regulators did not interact with grafting on percentage capsule set. Therefore, the effects of both treatments were additive and should be used together to increase capsule set in cultivars that responded to growth regulator application:

Number of seeds produced in response to growth regulator application depended on cultivar (Table 3). Application of $\mathrm{GA}_{3}$ to 'Jewel', 2,4-D or ethephon to 'Shore Gold', and BA, GA, or ethephon to 'Vardaman' plants resulted in higher seed production than the controls. Grafted plants produced more seeds than nongrafted plants within all cultivars. Nongrafted plants of all cultivars, except 'Southern Delite', prodqced essentially no seeds (Table 3 ). There was no interaction between the effects of grafting and growth regulators on numbers of seeds produced.
Therefore, grafting and growth regulator effects were additive and should be used in combination to obtain the highest number of seeds on cultivars that responded positively to growth regulator application. For example, with 'Shore Gold', no seeds were obtained on plants with grafting alone or with growth regulators alone, but some seeds were produced'from grafted plants receiving either the ethephon or 2,4-D treatments.

Due to the cultivar $\times$ growth regulator interaction for numbers of seeds produced, a standard recommendation for the use of growth regulators in combination with grafting to increase seed production cannot be made. The results of this study do show that growth regulator application in combination with grafting can be valuable for producing seeds on low or nonflowering genotypes such as 'Shore Gold'. However, preliminary trials to determine the optimum growth regulators for different genotypes will be necessary. Based on the results shown in Table 3, we have applied a combination of BA, ethephon, and $\mathrm{GA}_{3}$ to grafted plants in polycross nurseries and empirically found it effective in increasing seed production.

\section{Literature Cited}

Charles, W. B., D.G. Hoskin, and P.J. Cave. 1974. Overcoming cross- and self-incompatibility in Ipomoea batatas (L.) Lam. and Ipomoea trichocarpa (Elliot). J. Hort. Sci. 49:113-121.

Dukes, P.D. and A. Jones. 1981. The influence and evaluation of rootstock of Ipomoea camea ssp. fistulosa on inducing flowering and seed development of sweet potato scions. HortScience 16(3):288. (Abstr.)

Folquer, F. 1961. Inducción de floración y fructificación en batatas mediante injerto sobre Ipomoea fistulosa. Facultad de Agronomía y Zootecnia. Universidad National de Tucumán, Argentina. Miscelánia no. 11.

Folquer, F. and L.R. Roncedo. 1974. Eficiencia varietal en la producción primaveral de semillas de batata [Ipomoea batatas (L.) Lam.]. Rev. Agron. Noroeste Argentine. 11(3/4):193-225.

Howell, M.J. and S.H. Wittwer. 1954. Chemical induction of flowering in the sweet potato. Science 120:717.

Howell, M.J. and S.H. Wittwer. 1955. Further studies on the effect of 2,4-D on flowering in the sweet potato. Proc. Amer. Soc. Hort. Sci. 66:279-283.

Kehr, A. E., T.C. Ting, and J.C. Miller. 1955. Induction of flowering in the Jersey type sweet potato. Proc. Amer. Soc. Hort. Sci. 62:437 440.

Lam, S.L. and H.B. Cordner. 1955. Flowering hormone in relation to blooming in sweet potatoes. Science 121:140-141.

Lam, S. L., A.E. Thompson, and J.P. McCollum. 1959. Induction of flowering in the sweet potato. Proc. Amer. Soc. Hort. Sci. 73:453-462.

Lardizabal, R.D. and P.G. Thompson. 1988. Hydroponic culture, grafting, and growth regulators to increase flowering in sweet potato. HortScience 23:993-995.

Suge, H. 1977. Promotion of flowering in sweet potato by gibberellin $\mathrm{A}_{3}$ and $\mathrm{A}_{7}$. Jpn. J. Breed. 27(3):251-256

Zobel, M.P. and G.C. Hanna. 1953. Flower induction in sweet potato. Calif. Agr. 7(7):13. 